\title{
A perspective on bats (Chiroptera)
}

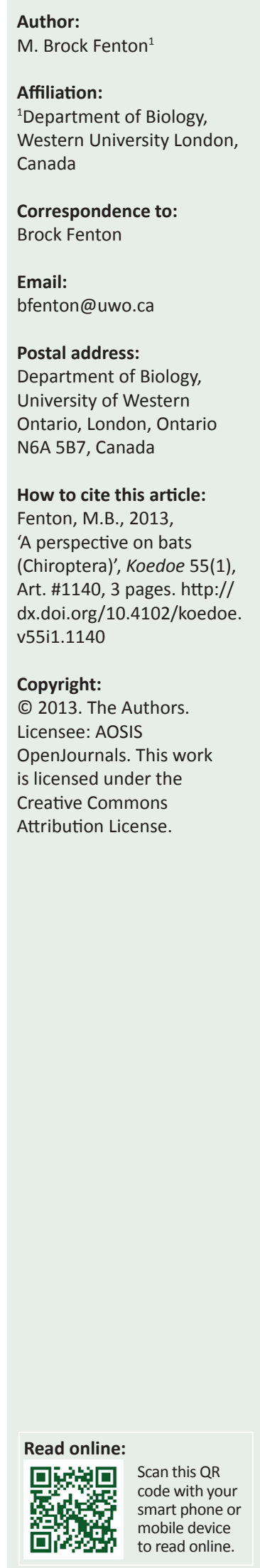

With over 130 species, bats are the most diverse group of mammals almost everywhere in subSaharan Africa. Since 2000, two books (Monadjem et al. 2010; Taylor 2000) have made it much easier to appreciate this reality. Species previously unrecognised are frequent discoveries (e.g. Taylor et al. 2012). Whilst most species are mainly insectivorous, some rely more directly on plants, taking fruit and visiting flowers to obtain nectar and pollen. The combination of mobility, long lifespan and diversity of trophic roles makes bats potentially valuable as indicators of ecosystem health (Cumming \& Spiesman 2006). Lack of detailed information, however, makes it easy to overlook bats when focusing on issues of conservation.

The advent of DNA barcoding (Hebert et al. 2003) has provided a valuable means of identifying cryptic diversity in bats (e.g. Clare, Lim, Fenton \& Hebert 2011). Barcoding also has allowed biologists to obtain precise information about what bats eat (e.g. Clare et al. 2009; Clare, Barber, Sweeney, Hebert \& Fenton 2011). This development can allow us to test the common belief that bats deliver important ecosystem services as consumers of insect pests (e.g. Cleveland et al. 2006; Kalka \& Kalko 2006) and assess their roles as dispersers of seeds and pollinators of plants (Mello et al. 2011). DNA barcoding also allows us to explore various aspects of the evolution and ecology of bats, including interactions with insect prey (Goerlitz et al. 2010). In Neotropical forests, reduced biomass of insects appears to be linked to the activity of bats and birds (Morrison \& Lindell 2012). Meanwhile, the presence and relative densities of bats in agricultural landscapes reflects tree density and probably the availability of roosts (Hanspach et al. 2012).

Echolocation provides a window on the activity, behaviour and ecology of most bats. Exceptions to this generalisation are pteropodids, which mainly do not echolocate, and some other bats that produce low intensity echolocation signals. Whether the tongue click echolocation signals of Rousettus aegyptiacus (the echolocating pteropodid in Africa) (Yovel et al. 2010) can be used to monitor activity remains to be determined and bats using low intensity echolocation calls are much less conspicuous than those using high intensity calls. All of the approximate 95 nonpteropodids in sub-Saharan Africa have the capacity for echolocation and produce echolocation calls in their voice boxes (larynges) (Veselka et al. 2010).

Identification of many species of bats by their echolocation calls can be a routine exercise (e.g. Walters et al. 2012). Acoustic identification of species depends on the number of species in the fauna under consideration and knowledge of the echolocation of each of these species. Information about distribution and levels of activity in different habitats can be advantageous in preparing environmental impact assessments. It could be argued, however, that large-scale monitoring of bat echolocation calls is not for the faint of heart; there are at least two important challenges.

Firstly, bat detecting systems must be as sensitive as possible and provide maximum data to be used in identification of species. This means using recording systems that provide full spectrum recordings. Not all systems are equally sensitive and differ in their degree of directionality (e.g. Adams et al. 2012). Even though many largyneally echolocating bats produce intense echolocation calls (Holderied et al. 2005; Surlykke \& Kalko 2008), when sounds > $30 \mathrm{kHz}$ dominate echolocation calls they do not travel far in air because of atmospheric attenuation (Lawrence \& Simmons 1982). When choosing a bat detector, there are important points to bear. These include the frequency response of the system matching the frequencies used by the bats you plan to study and the detectability of echolocation calls with different acoustic features.

Secondly, when searching for prey, echolocating bats produce large numbers of calls (from 1-20 calls per second) and working with recorded echolocation calls means handling very large datasets. Making full use of the datasets requires good curation, experienced observers, and effective software. Assessing the diagnostic (species-specific) echolocation calls is the root of 
successful monitoring (Walters et al. 2012). Whilst examining calls can provide an indication of how many species are involved, assigning names to call types may be more difficult. Flying bats in a room, a tent or along a zipline is unlikely to provide much assistance in assigning species names to call types. Documenting and accounting for intraspecific variation is a key to successfully identifying bats by their echolocation calls.

Proposals to erect commercial wind facilities (i.e. wind farms) provide an immediate reason for assessing levels of bat activity and diversity. We know that bats are killed at such facilities (e.g. Baerwald \& Barclay 2011; Rydell et al. 2012; Subramanian 2012), but lack of knowledge about how bats use habitat and landscape features means that we are rarely proactive in deciding where to place turbines to minimise bats' exposure to them. Minimising bats' exposure to turbines might be as 'easy' as programming turbines to shut down when bats are active around them. However, data from a bat detector deployed at ground level, or even $10 \mathrm{~m}$ above it, will not sample calls produced by bats active in the air space swept by a turbine with $30 \mathrm{~m}$ long blades and nacelle $60 \mathrm{~m}$ above the ground (Adams et al. 2012). Clearly bats flying above the nacelle also will not be sampled. Calls received by a bat detector placed at the nacelle of a turbine, however, could be one way to determine when to shut down the turbine. Nicholls and Racey (2009) suggested that bats avoid electromagnetic radiation, perhaps offering another way to reduce bat mortality at wind turbines.

Bats are long-lived animals of low fecundity. In some species, high levels of mortality during a bat's first year (e.g. the African Eidolon helvum) (Hayman et al. 2012) make populations susceptible to further changes in survivorship. This life history characteristic (Barclay \& Harder 2006) makes bats particularly vulnerable to additional mortality factors such as those associated with turbines at wind farms.

The increasing association of bats with the epidemiology of certain diseases that affect humans influences human perceptions of bats, presenting a challenge to those concerned about their conservation. In the past, the deadly nature of rabies made it a principal focus of how bats are involved with public health (Kuzmin \& Rupprecht 2007). There are many reports of new and emerging diseases alleged to involve bats, of which Severe Acute Respiratory Syndrome (SARS) is one example (Dobson 2005; Li et al. 2005); although, the evidence for this may not be convincing (Fenton et al. 2006; Salazar-Bravo et al. 2006). More recently, a virus causing a bat-specific strain of influenza has been reported from Central America (Tong et al. 2012), with little information about whether or not it has been transmitted to humans, let alone its effect on them. In other cases, for example Ebola, the impact on humans is clear and there is evidence of the role that bats play as a reservoir (Leroy et al. 2005). Sometimes the link to bats is not as clear, for example with Bas-Congo virus (BASV), a rhabdovirus that causes acute haemorrhagic fever and which appears more closely related to rabies virus (Grard et al. 2012). In Spain, presence of a genetically distinct filovirus in insectivorous bats appears to have been involved in a large die-off that occurred in 2002 (Negredo et al. 2011). The implications of this filovirus for human health remain unclear. Wang, Walker and Poon (2011) proposed that bats present a 'special' reservoir for emerging viruses. Interestingly, Stockman et al. (2008) found no evidence for antibodies to coronaviruses in bat biologists. This raises the possibility that bat biologists could serve as 'canaries in the coal mine' when it comes to exploring implications of disease-causing organisms for humans.

Disease is a two-way street. The appearance and rapid spread of white-nose syndrome (WNS) amongst hibernating bats in eastern North America (Frick et al. 2010; Lorch et al. 2011) has had a devastating impact on populations of bats that hibernate underground. The mortality is caused by the European strain of Geomyces destructans (Warenke et al. 2012) that was accidently introduced to some caves near Albany, New York. The rapid spread of WNS over much of northeastern North America surely reflects bat-to-bat transmission during swarming behaviour (Fenton 2012). This situation should serve as a warning for those who study bats to avoid replicating the calamity elsewhere.

Bats provide astonishing examples of diversity, from Kerivoula hardwickii that roost in pitchers of Nepenthes rafflesiana (Grafe et al. 2011), to bats that hunt copulating flies, doubling their energy intake from a single attack (Siemers et al. 2012). Some species of bats thrive in cities and urban areas, providing yet another perspective on their adaptability, whether the focus is on a species, for instance Otomops martiensseni (Fenton et al. 2004), or the bat community of a city (Coleman \& Barclay 2011). Then there are species that remain a mystery: whether the question is where they roost, such as Myotis welwitschii, or the role of an erectile crest in behavioural displays of male Chaerephon chapini. But my favourite mystery is the behavioural and/or ecological significance of the white wings and jet black fur of Necromicia tenuipinnis. Bats surely are gifts that keep on giving!

\section{Acknowledgements}

I thank Amanda Adams, Beth Clare, Eleanor Fenton, Rachel Hamilton, Liam McGuire and Toby Thorne for reading and commenting on an earlier version of this manuscript. My research on bats has been supported by grants from the Natural Sciences and Engineering Research Council of Canada and the Kenneth M. Molson Foundation.

\section{Competing interests}

The author declares that he has no financial or personal relationships which may have inappropriately influenced him in writing this article.

\section{References}

Adams, A.M., Jantzen, M.K., Hamilton, R.M. \& Fenton, M.B., 2012, 'Do you hear what I hear? Implications of detector selection for acoustic monitoring of bats' Methods in Ecology and Evolution 3, 992-998. http://dx.doi.org/10.1111/j.2041210X.2012e.00244.x 
Baerwald, E.F. \& Barclay, R.M.R., 2011, 'Patterns of activity and fatality of migratory bats at a wind energy facility in Alberta, Canada', Journal of Wild life Management 75, 1103-1114. http://dx.doi.org/10.1002/jwmg.147

Barclay, R.M.R. \& Harder, L.D., 2006, 'Life histories of bats: Life in the slow lane', in T.H. Kunz \& M.B. Fenton (eds.), Bat ecology, pp. 209-256, University of Chicago Press, Chicago.

Cleveland, C.J., Betke, M., Federico, P., Frank, J.D., Hallam, T.G., Horn, J. et al., 2006 'Economic value of the pest control service provided by Brazilian free-tailed bats in south-central Texas', Frontiers in Ecology 4, 238-243. http://dx.doi org/10.1890/1540-9295(2006)004[0238:EVOTPC]2.0.CO;2

Clare, E.L., Fraser, E., Braid, H., Fenton, M.B. \& Hebert, P.D.N., 2009, 'Unravelling complex food webs with simple molecules: A generalist predator the eastern red http://dx.doi.org/10.1111/j.1365-294X.2009.04184.x, PMid:19457192

Clare, E.L., Lim, B.K., Fenton, M.B. \& Hebert, P.D.N., 2011, 'Neotropical bats: Estimating species diversity with DNA barcodes', PLOS ONE 6(7), e22648. http:// dx.doi.org/10.1371/journal.pone.0022648, PMid:21818359 PMCid:3144236

Clare, E.L., Barber, B.R., Sweeney, B.W., Hebert, P.D.N. \& Fenton, M.B., 2011 'Eating local: Influences of habitat on the diet of little brown bats (Myotis lucifugus)', Molecular Ecology 20, 1772-1780. http://dx.doi.org/10.1111/j.1365294X.2011.05040.x, PMid:21366747

Coleman, J.L. \& Barclay, R.M.R., 2011, 'Influence of urbanization on demography of little brown bats (Myotis lucifugus) in the prairies of North America', PLOS ONE 6(5), e20483. http://dx.doi.org/10.1371/journal.pone.0020483

Cumming, G.S. \& Spiesman, B.J., 2006, 'Regional problems need integrated solutions: Pest management and conservation biology in agroecosystems', Biological Conservation 131, 533-543. http://dx.doi.org/10.1016/j.biocon.2006.02.025

Dobson, A.P., 2005, 'What links bats to emerging infectious diseases?', Science 310 629-629. http://dx.doi.org/10.1126/science.1120872, PMid:16254175

Fenton, M.B., 2012, 'Bats and white-nose syndrome', Proceedings of the National Academy of Sciences of the United States of America 109, 6794-6795. http:// dx.doi.org/10.1073/pnas.1204793109

Fenton, M.B., Jacobs, D.S., Richardson, E.J., Taylor, P.J. \& White, W., 2004, 'Individual signatures in the frequency-modulated sweep calls of large African large-eared free-tailed bats (Otomops martiensseni; Chiroptera: Molossidae)', Journal of Zoology (London) 262, 11-19. http://dx.doi.org/10.1017/S095283690300431X

Fenton, M.B., Davison, M., Kunz, T.H., McCracken, G.G., Racey, P.A. \& Tuttle, M.D., 2006, 'Linking bats to emerging diseases', Science 311, 1098-1099. http://dx.doi. org/10.1126/science.311.5764.1098c, PMid:16497913

Frick, W.F., Pollock, J.F., Hicks, A.C., Langwig, K.E., Reynolds, D.S., Turner, G.G. et al., 2010, 'An emerging disease causes regional population collapse of a common North American bat species', Science 329, 679-682. http://dx.doi.org/10.1126/ science.1188594, PMid:20689016

Goerlitz, H.R., Ter Hofstede, H.M., Zeale, M.R.K., Jones, G. \& Holderied, M.W., 2010 'An aerial-hawking bat uses stealth echolocation to counter moth hearing', Current Biology 20, 1-5.

Grafe, T.U., Schoner, C.R., Kerth, G., Junaidi, A. \& Schoner, M.G., 2011, 'A novel resource-service mutualism between bats and pitcher plants', Biology Letters 7 436-439. doi:10.1098/rsbl.2010.1141. http://dx.doi.org/10.1098/rsbl.2010.1141

Grard, G., Fair, J.N., Lee, D., Slikas, E., Steffen, I., Muyembe, J-J. et al., 2012, 'A novel rhabdovirus asocaited with acute hemorrhagic fever in Central Africa', PLOS Pathogens 8(9), e1002924. http://dx.doi.org/10.1371/journal.ppat.1002924, PMid:23028323 PMCid:3460624

Hanspach, J., Fischer, J., Ikin, K., Stott, J. \& Law, B.S., 2012, 'Using trait-based filtering as a predictive framework for conservation: a case study of bats on farms in southeastern Australia', Journal of Applied Ecology 49, 842-850. http://dx.doi. org/10.1111/j.1365-2664.2012.02159.x

Hayman, D.T.S., McCrea, O., Restif, R., Suu-Ire, R., Fooks, A.R., Wood, J.L.N. et al., 2012, 'Demography of straw-colored fruit bats in Ghana', Journal of Mammalogy 93 1393-1404. http://dx.doi.org/10.1644/11-MAMM-A-270.1

Hebert, P.D.N, Cywinska, A., Ball, S.I. \& DeWaard, J.R., 2003, 'Biological identifications through DNA barcodes', Proceedings of the Royal Society B 270, 313-321. http:// dx.doi.org/10.1098/rspb.2002.2218, PMid:12614582 PMCid:1691236

Holdereid, M.W., Korine, C., Fenton, M.B., Parsons, S., Robson, S. \& Jones, G., 2005, 'Echolocation call design and intensity in the aerial hawking bat, Eptesicus bottae (Vespertilionidae)', Journal of Experimental Biology 208, 1321-1327. http:// dx.doi.org/10.1242/jeb.01528, PMid:15781892

Kalka, M. \& Kalko, E.K.V., 2006, 'Gleaning bats as underestimated predators of herbivorous insects: Diet of Micronycteris microtis (Phyllostomidae) in Panama', Journal of Tropical Ecology 22, 1-10. http://dx.doi.org/10.1017/ S0266467405002920

Kuzmin, I.V. \& Rupprecht, C.E., 2007, 'Bat rabies', in A.C. Jackson \& W.H. Wunner (eds.), Rabies, 2nd edn., pp. 259-307, Elsevier, Amsterdam.
Lawrence, B.D. \& Simmons, J.A., 1982, 'Measurements of atmospheric attenuation at ultrasonic frequencies and the significance for echolocation by bats', Journal of the Acoustical Society of America 71, 585-590. http://dx.doi.org/10.1121/1.387529, PMid:7085967

Leroy, E.M., Kumulungul, B., Pourrut, X., Rouquet, P., Hassainin, A., Yaba, P. et al. 2005, 'Fruit bats as reservoirs of Ebola virus', Nature 438, 575-576. http://dx.doi. org/10.1038/438575a, PMid:16319873

Li, W., Shi, Z., Yu, M., Ren, W., Smith, C., Epstein, J.H. et al., 2005, 'Bats are natural reservoirs of SARS-like coronaviruses', Science 310, 676-679. http://dx.doi. org/10.1126/science.1118391, PMid:16195424

Lorch, J.M., Meteyer, C.U., Behr, M.J., Boyles, J.G., Cryan, P.M., Hicks, A.C. et al., 2011, 'Experimental infection of bats with Geomyces destructans causes white-nose syndrome', Nature 480, 376-378. http://dx.doi.org/10.1038/nature10590

Mello, M.A.R., Marquitti, F.M.D., Guimares, P.R. Jnr., Kalko, E.K.V., Jordano, P. \& De Aguiar, M.A.M., 2011, 'The missing part of seed dispersal networks: Structure
and robustness of bat-fruit interactions', PLOS ONE 6(2), e17395. http://dx.doi. org/10.1371/journal.pone.0017395, PMid:21386981 PMCid:3046224

Monadjem, A., Taylor, P., Cotterill, F.P.D. \& Shoeman, M.C., 2010, Bats of southern and central Africa, Wits University Press, Johannesburg.

Morrison, E.B. \& Lindell, C., 2012, 'Birds and bats reduce insect biomass and leaf damage in torpical forest restoration sites', Ecological Applications 22, 1526-1534.

Negredo, A., Palacios, G., Vazquez-Moron, S., Gonzalez, F., Dopazo, H. \& Molero, F., 2011, 'Discovery of an ebolavirus-like filovrius in Europe', PLOS Pathogens 7(10), 1002304. http://dx.doi.org/10.1371/journal.ppat.1002304, PMid:22039362 PMCid:3197594Nicholls, B. \& Racey, P.A., 2009, 'The aversive effect of electromagnetic radiation on foraging bats - A possible means of discouraging bats from approaching wind turbines', PLOS ONE 4, e6246. http://dx.doi. org/10.1371/journal.pone.0006246, PMid:19606214 PMCid:2705803

Rydell, J., Engstrom, H., Hedenstrom, A., Larsen, J.K., Pettersson, J. \& Green, M., 2012 The effect of wind power on bats and birds, a synthesis, report 6511, Swedish Environmental Protection Agency, Stockholm.

Salazar-Bravo, J., Phillips, C.J., Bradley, R.D., Baker, R.J., Yates, T.L. \& Ruedas, L.A., 2006, 'Voucher specimens for SARS-linked bats', Science 311, 1099-1020. http://dx.doi. org/10.1126/science.311.5764.1099, PMid:16497914

Siemers, B.M., Kriner, E., Kaiph, I., Simon, M. \& Greif, S., 2012, 'Bats eavesdrop on the sound of copulating flies', Current Biology 22(14), R563. http://dx.doi. org/10.1016/j.cub.2012.06.030, PMid:22835788

Stockman, L.J., Haynes, L.M., Miao, C., Harcourt, J.L., Rupprecht, C.E., Ksiazek, T.G. et al., 2008, 'Coronavirus antibodies in bat biologists', Emerging Infectious Diseases 14, 999-1000. http://dx.doi.org/10.3201/eid1406.070964, PMid:18507931 PMCid:260027

Subramanian, M., 2012, 'An ill wind', Nature 486, 310-311. http://dx.doi. org/10.1038/486310a, PMid:22722172

Surlykke, A. \& Kalko, E.K.V., 2008, 'Echolocating bats cry out loud to detect their prey', PLOS ONE 3(4), e2036. http://dx.doi.org/10.1371/journal.pone.0002036, prey', PLOS ONE 3(4), e2036. h
PMid:18446226 PMCid:2323577

Taylor, P.J., 2000, Bats of southern Africa, University of Natal Press, Pietermaritzberg.

Taylor, P.J., Stoffberg, S., Monadjem, A., Shoeman, M.C., Baylis, J. \& Cotterill, F.P.D., 2012, 'Four new bat species (Rhinolophus hildebrandii complex) reflect PlioPleistocene divergence of dwargs and gians across an afromontane archipelago', PLOS ONE 7(9), e41744. http://dx.doi.org/10.1371/journal.pone.0041744, PMid:22984399 PMCid:3440430

Tong, S., Li, Y., Rivailler, P., Conrardy, C., Castillo, D.A.A., Chen, L-M. et al., 2012, 'A distinct lineage of influenza A virus from bats', Proceedings of the National Academy of Sciences of the United States of America 109, 4269-4279.

Veselka, N., McErlain, D.D., Holdsworth, D.W., Eger, J.L., Chhem, R.K., Mason, M.J. et al., 2010, 'A bony connection signals laryngeal echolocation in bats', Nature 463, al., 2010, 'A bony connection signals laryngeal ech
939-942. http://dx.doi.org/10.1038/nature08737

Walters, C., Freeman, R., Dietz, C., Fenton, B., Jones, G., Maltby, A. et al., 2012, 'A continental-scale tool for acoustic identification of European bats', Journal of Applied Ecology 49, 1064-1074. http://dx.doi.org/10.1111/j.13652664.2012.02182.x

Wang, L-F., Walker, P.J. \& Poon, L.L.M., 2011, 'Mass extinctions, biodiversity and mitochondrial function: Are bats 'special' as reservoirs for emerging viruses?', Current Opinion in Virology 1, 649-657.

Warnecke, L., Turner, J.M., Bollinger, T.K., Lorch, J.M., Misra, V., Cryan, P.M. et al., 2012, 'Inoculation of bats with European Geomyces destructans supports the novel pathogen hypothesis for the origin of white-nose syndrome', Proceedings of the National Academy of Sciences of the United States of America 109, 6999-7003.

Yovel, Y., Falk, B., Moss, C.F. \& Ulanovsky, N., 2010, 'Optimal localization by pointing off axis', Science 327, 701-704. http://dx.doi.org/10.1126/science.1183310, PMid:20133574 